\title{
PENGARUH EKSTRAK BAWANG MERAH (Eleutherina americana) DENGAN MADU PADA MINUMAN FUNGSIONAL
}

\author{
Ningrum dwi Hastuti ${ }^{1)}$, Refid Ruhibnur ${ }^{1)}$ \\ ${ }^{1)}$ Politeknik Ketapang \\ email : ajeng.bima@yahoo.com \\ email : refide_maldini@yahoo.com
}

\begin{abstract}
Dayak onion also called onion Mecca (Eleutherine americana) is a typical plant in Central Kalimantan. This plant has been handed down Dayak community is used as a medicinal plant. Dayak onion processing into refined products it needs to be developed considering the sale of higher value than the fresh form. The purpose of this study was to determine the content of the antioxidant in onions Mecca and determine the best treatment combination between Mecca onion extract and honey to create chemically functional beverages and organoleptic tests. This study uses a Single randomized design with LSD 5\% on chemical parameters during boiling of 0, 5, 10, 15 and 20 minutes. Measurement of organoleptic test on color, flavor, and aroma using friedman test. The results showed that the highest antioxidant levels obtained during boiling 10 minutes amounted to $55.79 \%$ and the lowest in the boiling water for 0 minutes at $12.82 \%$. The best treatment is a combination of chemicals found at boiling for 10 minutes with antioxidants kada of 55.79\% and total phenolic amounted to $4514.70 \mathrm{mg} / \mathrm{g}$, whereas the best treatment combination on organoleptic test was obtained from a combination of onions mekah treatment that has been boiled for 10 minutes with the addition of $15 \mathrm{ml}$ honey with a value of 5.05 (flavor), 7.60 (color), and 7.45 (aroma).
\end{abstract}

Keywords: mecca onion extract, honey, functional drinks

\begin{abstract}
ABSTRAK
Bawang dayak juga disebut bawang mekah (Eleutherina americana) merupakan tanaman khas kalimantan tengah. Tanaman ini sudah turun temurun dipergunakan masyarakat dayak sebagai tanaman obat. Pengolahan bawang dayak menjadi produk olahan memang perlu dikembangkan mengingat nilai jual yang lebih tinggi daripada bentuk segar. Tujuan penelitian ini adalah mengetahui kandungan antioksidan dalam bawang mekah dan mengetahui kombinasi perlakuan terbaik antara ekstrak bawang mekah dan madu untuk membuat minuman fungsional secara kimia dan uji organoleptik. Penelitian ini menggunakan metode Rancangan Acak Tunggal dengan uji BNT 5\% pada parameter kimia selama perebusan 0, 5, 10, 15, dan 20 menit. Pengukuran uji organoleptik pada warna, rasa, serta aroma menggunakan uji Friedman. Hasil penelitian menunjukkan bahwa kadar oksidan tertinggi diperoleh selama perebusan 10 menit sebesar 55,79\% dan terendah pada perebusan selama 0 menit sebesar $12,82 \%$. Kombinasi perlakuan terbaik secara kimia didapatkan pada perebusan selama 10 menit dengan kada antioksidan sebesar $55,79 \%$ dan total fenolik sebesar $4514,70 \mathrm{mg} / \mathrm{g}$, sedangkan kombinasi perlakuan terbaik pada uji organoleptik didapatkan dari kombinasi perlakuan bawang mekah yang telah direbus selama 10 menit dengan penambahan madu sebanyak $15 \mathrm{ml}$ dengan nilai 5,05 (rasa), 7,60 (warna), dan 7,45 (aroma)
\end{abstract}

Kata kunci: ekstrak bawang mekah, madu, minuman fungsional

\section{PENDAHULUAN}

Bawang dayak juga disebut bawang mekah (Eleutherina Americana) merupakan tanaman khas Kalimantan Tengah. Tanaman ini sudah secara turun temurun dipergunakan masyarakat Dayak sebagai tanaman obat. Tanaman ini memiliki warna umbi merah dengan daun hijau berbentuk pita dan bunganya berwarna putih. Tumbuhan ini mudah dibudidayakan, penanamannya tidak 
tergantung musim dan dalam waktu 2 higga 3 bulan setelah tanam sudah dapat dipanen (Saptowalyono, 2007). Pengolahan Bawang dayak menjadi produk olahan memang perlu dikembangkan mengingat nilai jual yang lebih tinggi daripada bentuk segar. Salah satu bentuk pengolahan bawang dayak dapat dilakukan dengan perlakuan pemanasan, yaitu dengan direbus.

Salah satu upaya untuk mempertahankan produk minuman bawang dayak akibat pemanasan agar tetap berpotensi sebagai antioksidan alami, maka dikombinasikan dengan antioksidan alami yaitu seperti madu. Jaya (2008) meneliti mengenai sifat antioksidan madu terhadap pemanasan rimpang jahe selama 6 menit dan penambahan $15 \mathrm{ml}$ madu untuk membuat minuman fungsional.Hasil penelitian menunjukkan bahwa perpaduan antara rimpang jahe dan madu dapat sinergis dan meningkatakan aktifitas antioksidan. Begitu pula dengan Brown, Henderson and Hunt (2006) yang melaporkan mengenai perpaduan antara jahe Thailand dengan madu/ propolis memiliki kemampuan sebagai penangkap radikal bebas yang tinggi.

Pengaruh pemanasan dari bawang dayak tanpa bahan pelarut kimia dan pemanfaatan madu sebagai antioksidan untuk membuat formulasi minuman fungsional perlu dikaji lebih lanjut. Oleh karena itu, perlu dianalisis kadar total antosianin, dan aktifitas antioksidan dengan menggunakan metode penangkap radikal bebas DPPH.

\section{BAHAN DAN METODE}

\section{Tempat dan waktu penelitian}

Penelitian ini dilakukan di laboratorium Teknologi Hasil Pertanian Politeknik ketapang dan Universitas Gajah Mada.

\section{Bahan dan alat}

Bahan yang digunakan dalam penelitian ini adalah Bawang mekah yang diperoleh di daerah mulia kerta, suka bangun Kabupaten Ketapang.Bahan kimia dengan spesifikasi p.a (pro analisis) adalah: 1) DPPH $(1,1$ diphenyl-2-picrylhydrazyl), metanol (Merck) dan asam askorbat (Rheidel Hein) untuk analisis aktifitas penangkap radikal bebas; 2) Folin-Ciocalteu, $\mathrm{Na}_{2} \mathrm{CO}_{3} 7,5 \%$, asam galat semuanya dari Merck digunakan untuk analisis total fenol.

Alat-alat yang digunakan dalam analisis berupa timbangan digital (XP-1500, Jerman), vortex (Barnstead), sentrifus (EBA 20), Gas Chromatography-MassSpectrometry QP2010 (Shimadzu, Jepang), FTIR (Fourier Transform Infrared Spectrophotometer, Shimadzu Jepang), spektofotometer UV2100 (Unico), tabung reaksi (Pyrex), gelas ukur $50 \mathrm{ml}$ (Pyrex), erlenmeyer $250 \mathrm{ml}$ (Pyrex), labu ukur $100 \mathrm{ml}$ (Pyrex), pipet mikro10-100 $\mu$ l (Soccorex), pipet volum 1 $\mathrm{ml}$ (Assistance), pipet volum $5 \mathrm{ml}$ (HBG), beaker glass $250 \mathrm{ml}$ (Pyrex), corong pemisah $100 \mathrm{ml}$ (Schott-Duran), rak kayu tabung reaksi, Bubble Suck, buret, spatula, spatula panjang, Theromostirer, Magnetic Stirrer 3 $\mathrm{cm}$.

\section{Penelitian tahap I}

Penelitian ini dilakukan untuk mengetahui pengaruh kombinasi perlakuan dari kondisi bahan baku dan suhu pemanasan pada Bawang mekah terhadap aktifitas antioksidan yang akan diaplikasikan pada minuman fungsional.penelitian tahap I meliputi pembuatan minuman fungsional dengan variasi perebusan waktu yang terdiri dari lima level, yaitu $0,5,10,15$ dan 20 menit.

Perlakuan yang memiliki aktifitas antioksidan terbaik dari Bawang mekah dilakukan pengujian total fenolik (sebagai asam galat) dengan menggunakan metode Folin-Ciocalteu (Miliauskas et al., 2004), dan aktifitas antioksidan dengan menggunakan metode penangkap radikal bebas DPPH dan uji organoleptik. Hasil terbaik dilanjutkan digunakan dalam penelitian tahap II.

\section{Penelitian tahap II}

Jaya (2008) mengemukakan bahwa kombinasi jumlah konsentrasi madu yang dicampurkan dengan bahan lain adalah $47,316 \mathrm{~mL}$, sehingga interval konsentrasi madu yang didapat menjadi $15 \mathrm{~mL}, 30 \mathrm{~mL}$ 
dan $45 \mathrm{~mL}$. Kombinasi antara ekstrak bawang mekah dan madu dilarutkan dengan air yang dapat diminum (potable water) sampai $100 \mathrm{~mL}$ sebagai perbandingan jumlah solut terhadap jumlah larutan.

Perlakuan yang memiliki aktifitas antioksidan terbaik dari bawang mekah dilakukan pengujian total fenolik (sebagai asam galat) dengan menggunakan metode Folin-Ciocalteu (Miliauskas et al., 2004) dan aktifitas antioksidan dengan menggunakan metode penangkap radikal bebas DPPH. Analisis GC-MS dan FTIR dilakukan berdasarkan perlakuan terbaik dari uji organolpetik.

\section{Pengamatan parameter}

Parameter pada penelitian tahap 1 meliputi aktifitas antioksidan dengan menggunakan metode penangkap radikal bebas DPPH (Yamasaki et al., 1994), total fenolik (sebagai asam galat) dengan menggunakan metode Folin-Ciocalteu (Miliauskas et al., 2004). Analisis penelitian tahap II adalah uji organoleptik yang dianalisa menurut statistik nonparametrik dengan menggunakan uji Friedman (Steel and Torrie, 1989). Dilanjutkandengan pengujian total fenolik (sebagai asam galat) dengan menggunakan metode FolinCiocalteu dan aktifitas antioksidan dengan menggunakan metode penangkap radikal bebas DPPH.

\section{Analisa data}

Penelitian ini menggunakan metode Rancangan Acak Tunggal dengan uji BNT $5 \%$ pada parameter kimia selama perebusan $0,5,10,15$, dan 20 menit. Pengukuran uji organoleptik pada warna, rasa, serta aroma menggunakan uji friedman, sedangkan kombinasi perlakuan terbaik menggunakan metode indeks efektivitas.

\section{HASIL DAN PEMBAHASAN}

\section{Antioksidan}

Rerata kadar antioksidan pada berbagai kombinasi perlakuan antara kombinasi perlakuan dari kondisi bahan baku dan suhu pemanasan pada Bawang mekah terhadap aktifitas antioksidan berkisar antara 12,82 $55,79 \%$.

Hasil analisis sidik ragam memperlihatkan bahwa adanya perbedaan antara kondisi bahan baku dan suhu pemanasan pada Bawang mekah, serta interaksi antar perlakuan memberikan pengaruh sangat nyata pada uji BNT 5\% terhadap kadar antioksidan. Tabel 1 memperlihatkan uji BNT $(\alpha=0,05)$ kombinasi perlakuan terbaik kadar antioksidan yang diperoleh dari kondisi bahan yang telah dilakukan perebusan selama 10 menit sebesar $55,79 \%$ dan sangat berbeda nyata dengan yang lain.

Tabel 1. Rerata kadar antioksidan (\%) pada berbagai kombinasi perlakuan

\begin{tabular}{lcc}
\hline \multicolumn{1}{c}{ Kombinasi Perlakuan } & $\begin{array}{c}\text { Rerata Kadar } \\
\text { Antioksidan }(\%)\end{array}$ & $\begin{array}{c}\text { BNT } \\
(\alpha=0,05)\end{array}$ \\
\hline Perebusan selama 0 menit & $12.82 \mathrm{a}$ & \\
Perebusan selama 5 menit & $49.94 \mathrm{~d}$ & \\
Perebusan selama 10 menit & $55.79 \mathrm{e}$ & 0,04 \\
Perebusan selama 15 menit & $30.66 \mathrm{c}$ & \\
Perebusan selama 20 menit & $28.10 \mathrm{~b}$ & \\
\hline
\end{tabular}

Keterangan : Angka rerata yang diikuti dengan huruf yang sama pada kolom yang sama tidak berbeda nyata pada uji BNT 5\% 


\section{Total fenolik}

Tabel 2. Rerata kadar total fenolik (mg/g) pada berbagai kombinasi perlakuan

\begin{tabular}{lcc}
\hline \multicolumn{1}{c}{ Kombinasi Perlakuan } & Rerata Kadar Total Fenolik $(\%)$ & $\begin{array}{c}\text { BNT } \\
(\alpha=0,05)\end{array}$ \\
\hline Perebusan selama 0 menit & $382.01 \mathrm{a}$ & \\
Perebusan selama 5 menit & $4360.29 \mathrm{~d}$ & 0,04 \\
Perebusan selama 10 menit & $4514.70 \mathrm{e}$ & \\
Perebusan selama 15 menit & $2195.28 \mathrm{c}$ & \\
Perebusan selama 20 menit & $1964.83 \mathrm{~b}$ & \\
\hline
\end{tabular}

Keterangan : Angka rerata yang diikuti dengan huruf yang sama pada kolom yang sama tidak berbeda nyata pada uji BNT 5\%

Rerata kadar total fenolik pada berbagai kombinasi perlakuan antara kombinasi perlakuan dari kondisi bahan baku dan suhu pemanasan pada Bawang mekah terhadap total fenolik berkisar antara 382,01-4.514,7 $\mathrm{mg} / \mathrm{g}$.

Hasil analisis sidik ragam memperlihatkan bahwa adanya perbedaan antara kondisi bahan baku dan suhu pemanasan pada Bawang mekah, serta interaksi antar perlakuan memberikan pengaruh sangat nyata pada uji BNT 5\% terhadap kadar total fenolik. Tabel 2 memperlihatkan uji BNT $(\alpha=0,05)$ kombinasi perlakuan terbaik kadar total fenolik yang diperoleh dari kondisi bahan yang telah dilakukan perebusan selama 10

Tabel 3. Perlakuan terbaik parameter kimia menit sebesar 4.514,70 mg/g dan sangat berbeda nyata dengan yang lain.

\section{Pemilihan perlakuan terbaik parameter kimia}

Pemilihan perlakuan terbaik parameter kimia (antioksidan dan total fenolik) pada kombinasi perlakuan antara kondisi bahan bawang merah mekah dengan lama perebusan yang berbeda diperlihatkan pada Tabel 3.

Tabel 3 memperlihatkan perlakuan terbaik kimia berdasarkan kadar antioksidan dan total fenolik didapatkan dari perebusan bawang mekah selama 10 menit yaitu dengan nilai produk sebesar 1,00 dengan kadar antioksidan sebesar $55,79 \%$, total fenolik sebesar 4.514,7 mg/g.

\begin{tabular}{lccc}
\hline \multicolumn{1}{c}{ Kombinasi Perlakuan } & $\begin{array}{c}\text { Antioksidan } \\
(\%)\end{array}$ & $\begin{array}{c}\text { Total Fenolik } \\
(\mathrm{mg} / \mathrm{g})\end{array}$ & $\begin{array}{c}\text { Nilai } \\
\text { Produk }\end{array}$ \\
\hline Perebusan selama 0 menit & 12,82 & 382.01 & 0,00 \\
Perebusan selama 5 menit & 49,94 & 4360.29 & 0,91 \\
Perebusan selama 10 menit & $\mathbf{5 5 , 7 9}$ & $\mathbf{4 5 1 4 . 7 0}$ & $\mathbf{1 , 0 0 *}$ \\
Perebusan selama 15 menit & 30,66 & 2195.28 & 0,43 \\
Perebusan selama 20 menit & 28,10 & 1964.83 & 0,37 \\
\hline
\end{tabular}

\footnotetext{
* = perlakuan terbaik
} 


\section{Uji organoleptik}

\section{Warna}

Hasil uji organoleptik menyajikan bahwa rerata ranking kesukaan panelis terhadap warna dari kombinasi perlakuan antara bawang mekah yang telah direbus selama 10 menit dengan penambahan madu $(15 \mathrm{ml}, 30 \mathrm{ml}$, dan $45 \mathrm{ml})$ berkisar antara 5,05-7,6.

Hasil analisis Uji Friedman $(\alpha=0,05)$ berdasarkan uji perbandingan pada berbagai kombinasi perlakuan memberikan pengaruh nyata terhadap rerata kesukaan warna terhadap kombinasi perlakuan bawang mekah yang telah direbus selama 10 menit dengan penambahan madu $(15 \mathrm{ml}, 30 \mathrm{ml}$, dan $45 \mathrm{ml}$ ). Kombinasi perlakuan terbaik tingkat kesukaan panelis terhadap warna diperoleh dari kombinasi perlakuan bawang merah mekah yang telah direbus selama 10 menit dengan penambahan madu sebesar 15 $\mathrm{ml}$. Menurut panelis penambahan madu sebesar $15 \mathrm{ml}$, warna yang ditimbulkan oleh produk minuman ini sangat menarik yaitu seperti perpaduan antara kuning bening.

\section{Rasa}

Hasil uji organoleptik menyajikan bahwa rerata ranking kesukaan panelis terhadap rasa dari kombinasi perlakuan antara bawang mekah yang telah direbus selama 10 menit dengan penambahan madu $(15 \mathrm{ml}, 30 \mathrm{ml}$, dan $45 \mathrm{ml})$ berkisar antara 5,05-7,15.

Hasil analisis Uji Friedman $(\alpha=0,05)$ berdasarkan uji perbandingan pada berbagai kombinasi perlakuan memberikan pengaruh nyata terhadap rerata kesukaan rasa terhadap kombinasi perlakuan bawang mekah yang telah direbus selama 10 menit dengan penambahan madu $(15 \mathrm{ml}, 30 \mathrm{ml}$, dan 45 $\mathrm{ml})$. Kombinasi perlakuan terbaik tingkat kesukaan panelis terhadap rasa diperoleh dari kombinasi perlakuan bawang merah mekah yang telah direbus selama 10 menit dengan penambahan madu sebesar $30 \mathrm{ml}$. Menurut panelis penambahan madu sebesar $30 \mathrm{ml}$, rasa yang ditimbulkan oleh produk minuman ini adalah sangat tepat, karena tidak terlalul manis.

\section{Aroma}

Hasil uji organoleptik menyajikan bahwa rerata ranking kesukaan panelis terhadap aroma dari kombinasi perlakuan antara bawang mekah yang telah direbus selama 10 menit dengan penambahan madu $(15 \mathrm{ml}, 30 \mathrm{ml}$, dan $45 \mathrm{ml})$ berkisar antara 4,95-7,45. Semakin tinggi rerata ranking kesukaan panelis, maka tingkat kesukaan panelis terhadap aroma semakin besar.

Hasil analisis Uji Friedman $(\alpha=0,05)$ berdasarkan uji perbandingan pada berbagai kombinasi perlakuan memberikan pengaruh nyata terhadap rerata kesukaan aroma terhadap kombinasi perlakuan bawang mekah yang telah direbus selama 10 menit dengan penambahan madu $(15 \mathrm{ml}, 30 \mathrm{ml}$, dan $45 \mathrm{ml}$ ). Kombinasi perlakuan terbaik tingkat kesukaan panelis terhadap aroma diperoleh dari kombinasi perlakuan bawang merah mekah yang telah direbus selama 10 menit dengan penambahan madu sebesar 15 $\mathrm{ml}$. Menurut panelis penambahan madu sebesar $15 \mathrm{ml}$, aroma yang ditimbulkan oleh produk minuman ini sangat netral, artinya baunya tidak terlalu menyengat.

\section{Pemilihan perlakuan terbaik parameter organoleptik}

Penentuan perlakuan terbaik berbagai kombinasi perlakuan bawang mekah yang telah direbus selama 10 menit dengan penambahan madu $(15 \mathrm{ml}, 30 \mathrm{ml}$, dan $45 \mathrm{ml})$ dilakukan dengan menggunakan metode indeks efektivitas (Susrini, 2005). Metode ini dilakukan pada parameter organoleptik. Adapun parameter organoleptik meliputi; rasa, warna dan aroma. Penilaian perlakuan terbaik disajikan pada Tabel 4.

Tabel 4 memperlihatkan kombinasi perlakuan terbaik diperoleh dari kombinasi perlakuan bawang mekah yang telah direbus selama 10 menit dengan penambahan madu $15 \mathrm{ml}$ dengan nilai produk sebesar 0,553 dengan karakteristik sebagai berikut: rerata nilai tingkat kesukaan panelis terhadap rasa 5,05; warna 7,60 dan aroma 7,45. 


\section{Penelitian tahap II}

Tabel 4. Perlakuan terbaik uji organoleptik

\begin{tabular}{ccccc}
\hline Kombinasi Perlakuan & Rasa & Warna & Aroma & $\begin{array}{c}\text { Nilai } \\
\text { Produk }\end{array}$ \\
\hline $\begin{array}{l}\text { Bawang mekah yang telah direbus selama } \\
10 \text { menit dengan penambahan madu 15 ml }\end{array}$ & 5.05 & 7.60 & 7.45 & $0,553^{*}$ \\
$\begin{array}{l}\text { Bawang mekah yang telah direbus selama } \\
10 \text { menit dengan penambahan madu 30 ml }\end{array}$ & 7.15 & 5.05 & 5.60 & 0,504 \\
$\begin{array}{l}\text { Bawang mekah yang telah direbus selama } \\
10 \text { menit dengan penambahan madu 45 ml }\end{array}$ & 5.10 & 5.10 & 4.95 & 0,017 \\
\hline$*$ perlakuan terbaik & & & &
\end{tabular}

Tahap 2 pada penelitian ini adalah dengan menguji parameter kimia yaitu antioksidan dan total fenolik pada perlakuan terbaik yang didapatkan dari uji organoleptik, yaitu kombinasi perlakuan bawang mekah yang telah direbus selama 10 menit dengan penambahan madu $15 \mathrm{ml}$. Rerata kadar antioksidan pada kombinasi terbaik tersebut adalah sebesar $64,47 \%$, sedangkan kadar total fenolik sebesar $6.610,93 \mathrm{mg} / \mathrm{g}$.

\section{KESIMPULAN}

1. Kombinasi perlakuan dari kondisi bahan baku dan suhu pemanasan pada bawang mekah terhadap aktifitas antioksidan berkisar antara 12,82 - 55,79\%. Kombinasi perlakuan terbaik kadar antioksidan diperoleh dari bawang mekah yang telah direbus selama 10 menit sebesar $55,79 \%$ dan sangat berbeda nyata dengan yang lain.

2. Kombinasi perlakuan terbaik berdasarkan parameter kimia diperoleh dari perebusan bawang mekah selama 10 menit yaitu dengan nilai produk sebesar 1,00 dengan kadar antioksidan sebesar $55,79 \%$, total fenolik sebesar $4.514,7 \mathrm{mg} / \mathrm{g}$, sedangkan kombinasi perlakuan terbaik secra organoleptik diperoleh dari kombinasi perlakuan bawang mekah yang telah direbus selama 10 menit dengan penambahan madu $15 \mathrm{ml}$ dengan nilai produk sebesar 0,553 dengan karakteristik: rerata nilai tingkat kesukaan panelis terhadap rasa 5,05; warna 7,60 dan aroma 7,45

\section{DAFTAR PUSTAKA}

Adi, W. 2011. Sarang semut dan herbal bawang dayak diminati. http : // koran kaltim. com/ index. Samarinda. Tanggal akses 10 Desember 2011.

Gheldof, N. and N. J. Engeseth. 2002. Antioxidant capacity of honeys from various floral sources based on the determination of oxygen radical absorbance capacity and inhibition of in vitro lipoprotein oxidation in human serum samples. Abstrak Journal of Agr and Food Chem, 50 (10 ): 3050-3055.

Jaya, F. 2008. Efek proses pemanasan pada aktifitas antioksidan rimpang jahe gajah (Zingiber officnale roscoe) dan pemaanfaatan madu sebagai antioksidan alami untuk minuman fungsional. Tesis. Program Pasca Sarjana . Fakultas Teknologi Pertanian. Universitas Brawijaya Malang.

Kruawan, K. and K. Kangsadalampai. 2006. Antioxidant activity, phenolic compound contents and antimutagenic activity of some water extract of herbs. Thai J. Pharm. Sci.,30 : 28-35.

Kumalaningsih, S. 2006. Antioksidan alami. Cetakan 1. Trubus Agrisarana. Surabaya. 
Mommies, W.R. 2005. Kiat memilih madu dan khasiatnya. http://wrmindonesia.org/index 2.php?option $=$ cont ent\&do_pdf $=1 \& i d=342$.

Diakses tanggal : 13 Januari 2010.

Rusfidra. 2006. Prospek pengembangan budidaya perlebahan di indonesia. seminar nasional biologi. Fakultas MIPA, Universitas Negeri Semarang.

Saptowalyono, C.A. 2007. Bawang dayak, tanaman obat kanker yang belum tergarap. http : // www2. kompas. com/ ver1/ Kesehatan/ 0702/ 19/ 170611. htm.Palangkaraya. Tanggal akses 10 Desember 2011
Setyaningsih, D., Apriyantono, A., Sari,M.P., 2010. Analisis sensoris: untuk industri pangan dan agro. Penerbit IPB Press, Bogor.

Supiyanti S., Wulansari E.D., dan Kusmita L., 2010. Uji aktivitas antioksidan dan penentuan kandungan antosianin total kulit buah manggis (Garcinia mangostana 1). Majalah Obat Tradisional, 15(2): $64-70$.

Standar Nasional Indonesia. 2004. Madu. www.ebookpangan.com/EBOOK\%20GRATIS/Ebook\%20Panga n/SNI-01-3545-2004\%20(madu).pdf Diakses tanggal : 13 Januari 2010 
